\title{
MENINGKATKAN KEMAMPUAN PENJUMLAHAN BILANGAN BULAT MELALUI PENGGUNAAN MEDIA KARTU KOTIF BERBASIS ANIMASI POWER POINT PADA SISWA TUNARUNGU
}

\author{
Mirnawati \\ Program Studi Pendidikan Luar Biasa FKIP ULM \\ Mirnawati.plb@ulm.ac.id
}

\begin{abstract}
Abstrak
Keterbatasan bahasa dan komunikasi pada siswa tunarungu menyebabkan siswa tunarungu seringkali dianggap memiliki intelegensi yang rendah dan kesulitan memahami konsep yang abstrak termasuk dalam pelajaran matematika. Siswa tunarungu kelas V di SLB Pelambuan Banjarmasin menunjukkan kemampuan yang masih rendah dalam menyelesaikan soal penjumlahan bilangan bulat, dengan demikian penelitian ini bertujuan untuk meningkatkan kemampuan penjumlahan bilangan bulat pada siswa tunarungu melalui penggunaan kartu kotif berbasis animasi power point. Pendekatan penelitian menggunakan pendekatan kuatitatif dengan jenis penelitian pra eksperimen quasi eksperimen dengan desain $\mathrm{O} 1 \mathrm{O} 2 \mathrm{O} 3$ O4 X 05 O6 O7 O8. Subjek penelitian berjumlah lima orang siswa tunarungu kelas V SLB Pelambuan Banjarmasin. Teknik pengumpulan data menggunakan tes dan dokumentasi adapun analisis data menggunakan deskriptif kuantitatif. Hasil penelitian menunjukkan bahwa kemampuan penjumlahan siswa tunarungu pada pre test masih rendah dengan nilai tertinggi 20, sedangkan pada post test terjadi peningkatan yang signifikan hal tersebut terbukti dengan nilai tertinggi yang dicapai oleh siswapada post test mencapai angka 70. Dengan dmeikian dapat disimpulkan bahwa medi kartu kotif berbasis animasi dapat meningkatkan kemampuan penjumlahan bilangan bulat siswa tunarungu kelas $\mathrm{V}$ di SLB Pelambuan Banjarmasin.
\end{abstract}

Kata kunci: kartu kotif animasi power point, penjumlahan bilangan bulat, tunarungu.

\section{PENDAHULUAN}

Anak tunarungu merupakan salah satu anak berkebutuhan khusus. Anak tunarungu mengalami hambatan pendengaran baik sebagian mapun keseluruhan yang walaupun menggunakan alat bantu dengar tetap membutuhkan layanan pendidikan khusus. Anak tunarungu yang mengalami hambatan pendengaran berdampak langsung pada kemampuan bahasa dan komunikasi anak tunarungu. Kesulitan bahasa dan komunikasi anak tunarungu selanjutnya berpengaruh pada hampir semua aspek kehidupan anak tunarungu.

Keterbatasan bahasa dan komunikasi pada anak tunarungu menyebabkan anak tunarungu 
seringkali dianggap memiliki integensi yang rendah, padahal pada dasarnya anak tunarungu tidak mengalami masalah pada intelegensi, namun pada hal-hal yang bersifat verbal anak tunarungu menunjukkan kemampuan yang rendah. Terlepas dari itu anak tunarungu juga seringkali bermasalah pada lingkungan sosial baik di lingkungan keluaga, sekolah maupun masayarakat. Anak tunarungu seringkali menggunakan bahasa isyarat dalam berkomunikasi namun tidak semua orang disekitarnya dapat membaca bahasa isyarat tersebut, begitupun sebaliknya ketika orangorang sekitar mengajak anak tunarungu berkomunkasi denganmenggunakan bahasa verbal maka anak tunarungu jugaakan kesulitan dalam memahami pembicaraan. Kondisi yang demikian dapat berdampak pada kepribadian anak tunarungu, mereka cenderung menarik diri, merasa curiga dan sensitif yang belebihan serta emosi yang tidak stabil.

Anak tunarungu dengan segala hambatan dan keterbatasannya juga merupakan warga negara yang berhak mendapatkan pendidikan. Sebagaimana dalam Undang-Undang No. 20 tahun 2003 tentang Sistem Pendidikan Nasional Pasal 5 ayat (1): "Setiap warga negara mempunyai hak yang sama untuk memperoleh pendidikan yang bermutu", yang artinya bahwa setiap warga negara tanpa melihat kekurangan dan kelebihan yang ada padanya berhak memperoleh pendidikan yang baik. Selanjutnya ditegaskan dalam dalam UU sistem pendidikan nasional No. 20 Tahun 2003 pasal 5 bagian pertama; setiap warga negara mempunyai hak yang sama untuk memperoleh pendidikan yang bermutu, bagian ke dua; warga negara yang mempunyai kelainan fisik, emosional, mental, intelektual, dan atau sosial berhak memperoleh pendidikan khusus.

Layanan pendidikan untuk anak berkebutuhan khusus termasuk anak tunarungu tidak hanya di sekolah luar biasa tetapi juga di sekolah reguler penyelenggara pendidikan inklusif. Salah satu mata pelajaran yang tidak bisa lepas dalam kurikulum sekolah adalah mata pelajaran matematika. Mata pelajaran matematika merupakan mata pelajaran yang diajarkan dari sekolah dasar sampai perguruan tinggi hakikat dari matematika sendiri suatu objek mata pelajaran yang bersifat abstrak. Swanwick, Oddy, \& Roper (2005).matematika adalah ilmu pengetahuan yang didapat dengan berpikir (benalar). Matematika lebih menekankan kegiatan dalam dunia rasio (penalaran), bukan menekankan dari hasil eksperimen atau hasil observasi matematika terbentuk karena pikiran-pikiran manusia, yang 
berhubungan dengan ide, proses, dan penalaran. Salah satu materi dalam pembelajaran matematika yang membutuhkan penalaran adalah bilangan bulat (Raharjo \& Widyaiswara, 2004). Bilangan bulat merupakan bilangan bukan pecahan dapat negatif, nol, maupun negatif. Sa'dijah (2001:93) memisahkan bilangan bulat menjadi tiga bagian yaitu:Bilangan bulat positif, himpunan unsunya: 1, 2, 3, 4, 5.....Bilangan bulat negatif, himpunan unsurnya: $-1,-2,-3$, $-4,-5 . . .$. dan Bilangan nol, hanya satu yaitu bilangan nol (0)

Kompetensi dasar yang harus dicapai dalam materi bilangan bulat diantaranya adalah penjumlahan bilangan bulat, namun kompetensi ini masih dianggap sulit bagi siswa-siswa di reguler terlebih lagi bagi anak berkebutuhan khusus termasuk anak tunarungu karena sifatnya yang abstrak, juga karena tercampurnya tanda positif dan negatif dengan operasi hitung. Selain itu anak tunarungu yang mengalami hambatan dalam pendengaran akan sangat kesulitan dalam mencerna informasi atau pembelajaran dalam kelas. Anakanak dengan gangguan pendengaran, samahalnya dengan anak-anak pada umumnya, seharusnya belajarmatematika agar dapat hidup sebagai individu yang sukses, efektif, dan mandiri dalam masyarakat. Tanridiler., Uzuner., \& Girgin
(2015).Untuk memahami pengetahuan matematika, seseorang harus dapat menggabungkan pengetahuan prosedural dan konseptual dan memahamipenggunaan konsep dalam berbagai situasi (Kelly., Lang ., Pagliaro, 2003).

Rendahnya kemampuan anak tunarungu dalam menyelesaikan penjumlahan bilangan bulat tidak sekedar karena faktor intern berupa sifat bilangan bulat yang abstrak dan kondisi siswa tunarungu yang terhambat dalam pendengaran dan pengolahan informasi verbal. Tapi juga karena faktor ekstern temasuk kemampuan guru dalam melaksanakan pembelajaran penjumlahan bilangan bulat dikelas. Kegiatan pembelajaran matematika materi penjumlahan bilangan bulat pada siswa tunarungu bukanlah hal yang mudah dilakukan. Guru harus berusaha keras untuk mampu berkomunikasi dengan siswa, dan menciptakan kegiatan pembelajaran yang menarik sehingga materi penjumlahn bilangan bulat mudah dipahami oleh siswa tunarungu.

Upaya yang dapat dilakukan guru diantaranya adalah dengan penggunaan media pembelajaran. Asnawir \& Usman (2002) menjelaskan bahwa media adalah alat bantu apa saja yang dapat dijadikan sebagai penyalur pesan guna mencapai tujuan pembelajaran, selanjutnya 
Basyaruddin (2002) mengemukakan bahwa media adalah segala bentuk yang dipergunakan untuk proses penyaluran informasi. Dengan demikian dapat dikatakan bahwa media pembelajaran adalah mediamedia yang digunakan dalam pembelajaran, yaitu meliputi alat bantu guru dalam mengajar serta sarana pembawa pesan dari sumber belajar ke penerima pesan belajar (siswa).

Menentukan media pembelajaran yang akan digunakan harus disesuaikan dengan apa yang dibutuhkan oleh anak berkebutuhan khusus tunarungu. Selain itu, media pembelajaran juga harus dibuat semenarik mungkin sehingga anak berkebutuhan khusus seperti anak tuna rungu menjadi lebih semangat dan termotivasi dalam belajar serta apa yang disampaikan oleh guru atau pengajar juga dapat lebih mudah diterima oleh anak. Salah satu media pembelajaran yang dianggap cocok bagi anak tunarungu adalah media yang bersifat visual berupa animasi power point. Penggunaan media animasi power point ini merupakan media pembelajaran visual.

Penggunaan media animasi power point dalam pembelajaran penjumlahan bilangan bulat akan menampilkan animasi berupa cara kerja koin negatif dan koin positif dalam mengerjakan operasi hitung penjumlahan. Dengan demikian konsep penjumlahan bilangan bulat yang abstrak menjadi lebih konkrit dengan tampilan media koin positif dan negatif yang dikemas dalam animasi power point. Sehingga diharapkan dapat meningkatkan kemampuan siswa tunarungu dalam menyelesaikan penjumlahan bilangan bulat.

Kustianti(2014) hasil belajar siswa dengan menggunakan koin positif negatif pada penjumlahan bilangan bulat mencapai peningkatan yang tergolong tinggi hingga mencapai ketuntasan belajar secara klasikal.Nurhizra (2018) menunjukkan bahwa pembelajaran dengan menggunakan alat peraga kartu positif dan negatif dapat meningkatkan hasil belajar siswa tentang operasi hitung penjumlahan dan pengurangan bilangan bulat di kelas V SDN Tondo GDengan demikian, peneliti tertarik untuk melakukan penelitian dengan judul Efektifitas Penggunaan Media Kartu Kotif Berbasis Animasi Power Point dalam Meningkatkan Kemampuan Penjumlahan Bilangan Bulat pada Siswa Tunarungu Kelas V di SLB Pelambuan Banjarmasin.

\section{METODE}

Pendekatan yang digunakan pada penelitian ini menggunakan pendekatan kuantitatif. Menurut Sugiyono (2013) pendekatan 
kuantitatif dapat diartikan sebagai dan menggunakan analisis penelitian yang berlandaskan pada data.Metode yang digunakan dalam filsafat positivisme, penelitian yang penelitian ini adalah metode digunakan untuk populasi atau sampel, teknik pengumpulan data menggunakan instrumen penelitian eksperimen tipe quasi eksperimen dengan desain penelitian menggunakan time series design.

\section{$01020304 \times 05060708$}

\section{Gambar 1.desain penelitian}

Keterangan:

O1 O2 O3 O4 : Melakukan tes awal (pretest)

$X \quad$ :Intervensi

O5 O6 O7 O8 : Setelah diberikan intervensi (posttest)

Hasil pretest yang baik adalah $\mathrm{O} 1=\mathrm{O} 2=\mathrm{O} 3=\mathrm{O} 4$, dan hasil perlakuan yang baik adalah $\mathrm{O} 5=\mathrm{O} 6=\mathrm{O} 7=\mathrm{O} 8$. Besarnya pengaruh perlakuan adalah $(05+06+07+08)$

(01+02+03+04).subjekpenelitian ini adalah siswa tunarungu kelas V SLB Pelambuan Banjarmasin yang berjumlah 5 orang siswa tunarungu.Penelitian ini menggunakan dua variabel yaitu variabel bebas dan variabel terikat. Variabel bebas merupakan variabel yang mempengaruhi atau memberi pengaruh variabel yang laian, adapun variabel bebas dalam penelitian ini yaitu penggunaan media kotif berbasis animasi power point. Variabel terikat merupakan variabel yang dipengaruhi, adapun variabel terikat dalam penelitian ini yaitu kemampuan penjumlahan bilangan bulat.Pengumpulan data dilakukan untuk mengumpulkan data penelitian dalam mendukung proses penelitian agar mencapai tujuan yang direncanakan. Data dikumpulkan melalui tes, angket validasi, observasi dan dokumentasi.Data tentang kemampuan siswa dalam pembelajaran dianalisis dengan menggunakan statistik deskriptif kuantitatif dengan rumus sebagai berikut.

$$
\text { Nilai }=\frac{\text { jumlahskoryangdiperoleh }}{\text { skormaksimal }} \times 100
$$




\section{PEMBAHASAN}

\section{Kemampuan Penjumlahan Bilangan Bulat Siswa Tunarungu Pada Pre Test}

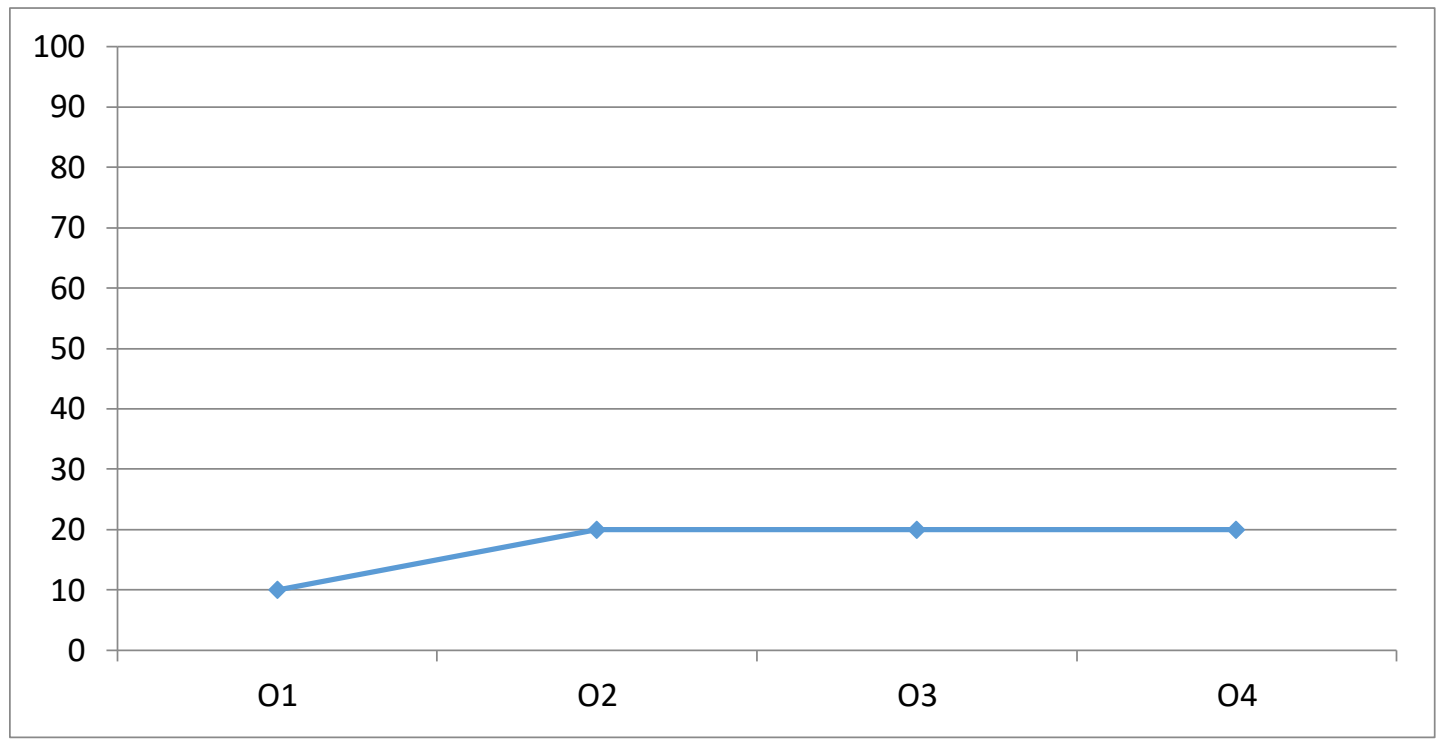

Gambar 2.

Grafik kemampuan penjumlahan bilangan bulat siswa tunarungu padapre test

Hasil kemampuan penjumlahan bilangan bulat siswa tunarungu pada pre test menunjukkan bahwa siswa tunarungu hanya dapat menjawab dua soal dengan benar dari sepuluh jumlah soal yang diberikan. Siswa tunarungu hanya dapat menjawab soal penjumlahan bilangan bulat yang menjumlahkan bilangan positif dengan bilangan positif misalnya $5+7$. Sedangkan untuk penjumlahan bilang positif dengan bilangan negatif maupun sebaliknya bilangan negatif dengan bilangan positif, siswa masih kebingungan karena berbaurnya tanda negatif dengan tanda operasional penjumlahan.

\section{Treatmen atau Intervensi}

Pada penelitian ini treatmen atau intervensi dilaksanakan dengan melaksanakan pembelajaran pada siswa tunarungu materi penjumlahan bilangan bulat dengan menggunakan media kartu kotif berbasis animasi power point, adapun metode pembelajaran yang digunakan adalah metode ceramah, demonstrasi atau simulasi dan pemberian tugas. Adapun langkah-langkah pemberian treatmen sebagai berikut.

a. Guru mengkondisikan dan menyiapkan siswa tunarungu untuk belajar

b. Guru melakukan apersepsi terkait materi penjumlahan bilangn bulat 
c. Guru mengenalkan madia kartu kotif (koin positif dan koin negatif) kepada siswa tunarungu

d. Guru memperlihatkan simulasi penyelesaian soal penjumlahan bilangan bulat menggunakan media kartu kotif melalui media animasi power point.

e. Siswa memperhatikan simulasi yang diperlihatkan

f. Guru menjelaskan kepadasiswa bahwa ketika koin negatif bertemu dengan koin positif maka nilainya sama dengan nol

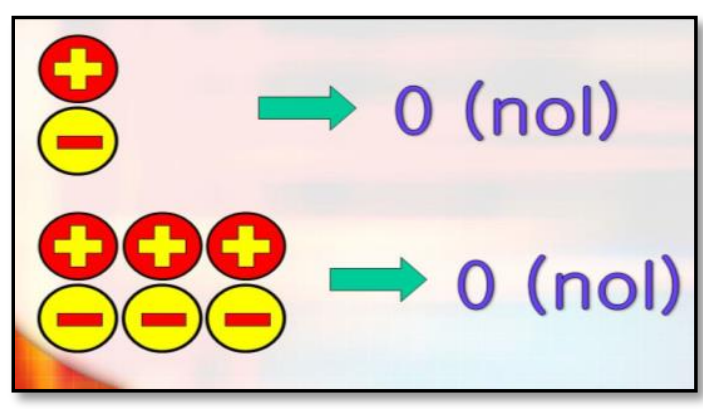

g. Mendampingi siswa untuk menyelesaikan soal penjumlahan menggunakan kartu kotif sesuai langkah-langkah yang disimulai dalam powerpoint.

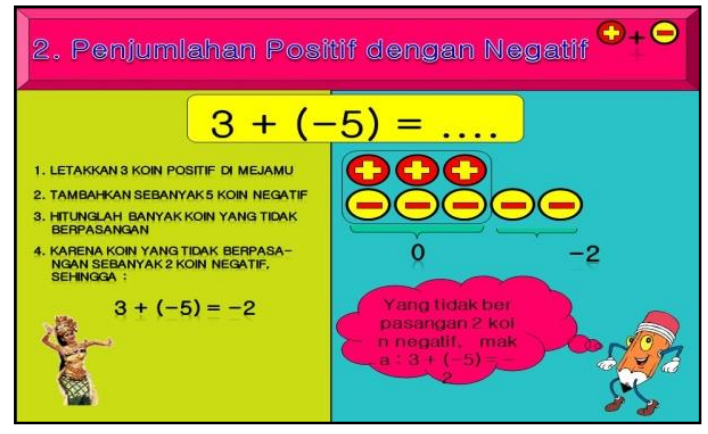

h. Guru memberikan beberapa soal penjumlahan bilangan bulat dan meminta siswa mengerjakan secara mandiri menggunakan kartu kotif. i. Siswa mengerjakan soal yang diberikan dan menanyakan kepadaguru terkait hal yang belum dipahami

j. Guru membimbing siswajika mengalami kesulitan.

\section{Kemampuan Penjumlahan Bilangan Bulat Siswa Tunarungu Pada Tahap Posttest}

Post test dilaksanakan selama empat hari untuk mengetahui kemampuan siswa tunanrungudalam menyelesaikan soal penjumlahan bilangan bulat setelah dierikan treatment/ intervensi berupa penggunaan media kartu kotif berbasis animasi power point dalam proses pembelajaran. Adapun hasil yang diperoleh siswa pada tahap post test ini, berikut divisualisasikan ke dalam bentuk grafik.

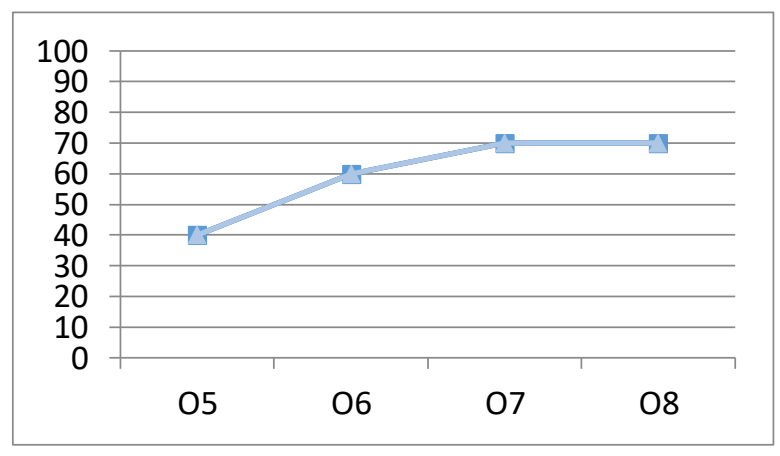

\section{Gambar 3}

Grafik kemampuan penjumlahan bilangan bulat siswa tunarungu pada posttest 
Hasil kemampuan penjumlahan bilangan bulat siswa tunarungu pada post test menunjukkan peningkatan, dalam hal ini siswa tunarungu hanya dapat menjawab sampai dengan tujuh soal dengan benar dari jumlah soal yang diberikan. Siswa tunarungu terlihat mulai mengerti menyelesaikan soal penjumlahan bilangn bulat campuran, hanya saja masih telihat bingung ketika penjumlah bilangan positi dengan bilangan negatif misalnya $7+(-$ 2), hal tersebut karena tanda negatif berdekatan dengantanda operasional penjumlahan, dan tidak ada masalah untuk penjumlahan bilangan negatif dengan bilangan positif.

Efektivitas penggunaan media kartu kotif berbasis animasi power point.

Efektivitas penggunaan media kartu kotif berbasis power point dalam meningkatkan kemampuan penjumlahan bilangan bulat siswa tunarungu dapat diketahui dnegan membandingkan hasil belajar siswa tunarungu pada pretest dan posttest. Adapun perbandingan kemampuan penjumlahan bilangan bulat siswa tunarungu pada pre test dan post test divisualisasikan ke dalam grafik berikut.

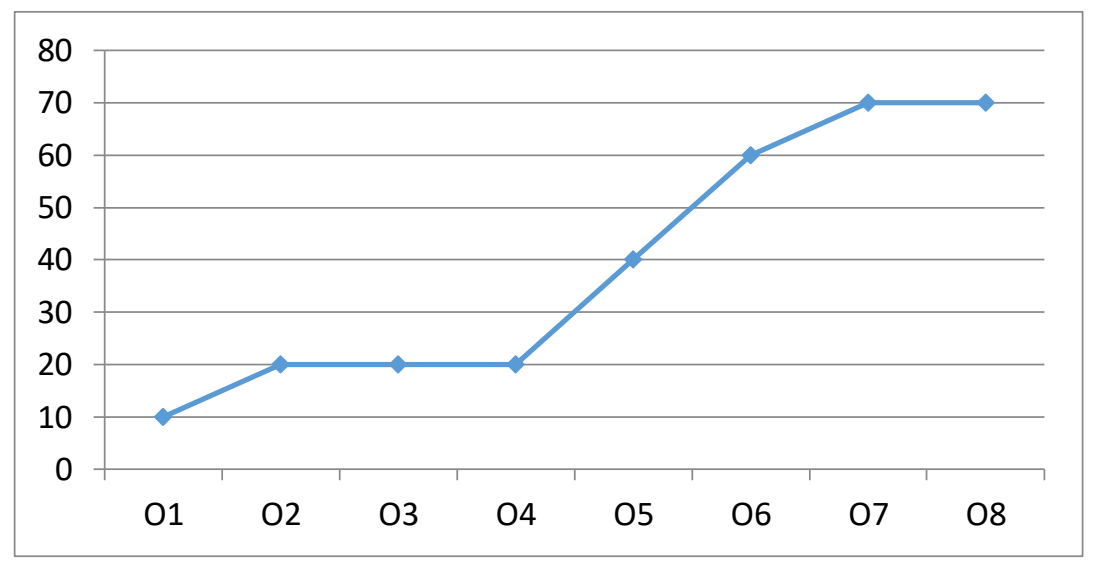

Gambar 4.

perbandingan kemampuan penjumlahan bilangan bulat siswa tunarungu pada pretest dan posttest

Grafik di atas menunjukkan skor tes kemampuan penjumlahan bilangan bulat terdapat perbedaan yang cukup signifikan sebelum dan sesudah diberikan intervensi berupa media kartu kotif berbasis animasi power point. Nilai pre test siswa adalah $\mathrm{O} 1=10 \quad \mathrm{O} 2=20 \quad \mathrm{O} 3=20 \quad$ dan $\mathrm{O} 4=20$ namun setelah penerapan media pembelajaran berbasis multimedianilai post test siswa adalah $\mathrm{O} 5=40 \quad \mathrm{O} 6=60 \quad \mathrm{O} 7=70$ dan $\mathrm{O} 8=70$. Dengan demikian dapat dikatakan bahwa penggunaan media media kartu kotif berbasis animasi power point efektif dalam meningkatkan kemampuan penjumlahan bilangan 
bulat siswa tunarungu kelas dasar $\mathrm{V}$ di SLBN Pelambuan Banjarmasin.

Kemampuan penjumlahan bilangan bulat siswa tunarungu pada pretest masih sangat rendah hal tersebut terlihat bahwa siswa hanya mampu menjawab paling banyak dua soal dari sepuluh soal yang diberikan. Hal tersebut dikarenakan karena anak tunarungu yang kurang konsep perbendaharaan kata sehingga berdampak pada pemahaman konsep matematika yang abstrak. Daniel Ling dalam Sadja'ah (2005) mengemukakan bahwa ketunarunguan memberikan dampak inti yang diderita oleh yang bersangkutan yaitu gangguan/hambatan perkembangan bahasa. Hambatan perkembangan bahasa memunculkan dampakdampak lain yang sangat kompleks lainnyas seperti aspek pendidikan, hambatan emosi-sosial, perkembangan inteligensi dan akhirnya hambatan dalam aspek kepribadian, artinya dampak inti yang di derita menimbulkan/mengait pada dampak lain yang mengganggu kehidupannya termasuk dalam memahami konsep matematika yang abstrak. Hidayat \&Suherman (2016) Perkembangan komunikasi anak tunarungu jika dibandingkan dengan anak yang mendengar sangat tertinggal jauh terutama dalam perbendaharaan kata dan dalam kemampuan menerima informasi.
Pembelajaran yang dilakukan sebelum pretes menggunakan metode ceramah dan penejelasan sederhana di papan tulis, dalam hal ini guru tidak menggunakan media ajar yang dapat memudahkan penyampaian konsep penjumlahan bilangan bulat. Proses pembelajaran yang berlangsung di dominasi oleh penjelasan secara lisan oleh guru sehingga siswa tunarungu mengalami kesulitan dalam memehami materi yang disampaiakan walaupun guru menggunakan bahasa yang sederhana. Suningsih\&Arnidha (2017) Kemampuan komunikasi matematis lisan pada pembelajaran matematika hanya efektif digunakan untu siswa tunarungu yang masih memilki sisa pendengaran..

Kemampuan penjumlahan bilangan bulat siswa tunarungu pada post test mengalami peningkatan secara signifikan, terlihat bahwa siswa telah mampu menjawab paling banyak tujuh soal dari sepuluh soal yang diberikan. Hal tersebut dikarenakan siswa tunarungu telah mendapatkan pembelajaraan materi penjumlahan bilangan bulat dengan menggunakan media kartu kotif berbasis animasi power point. Penggunaan media tersebut dapat mengubah konsep penjumlahan bilangan bulat yang abstrak menjadi konkrit, selain itu simulasi penggunaan kartu kotif dalam menyelesaikan soal penjumlahan bilangan bulat dalam 
bentuk animasi power point menjadikan anak lebih tertarik dan bersemangat dalam mengikuti pembelajaran, dan animasi power point yang sifatnya visual tersebut sangat sesuai dengan kondisi siswa tunarungu yang tipe belajarnya visual. Salim (2016) menyajikan materi matematika menggunakan animasi, gambar, teks dan videokegiatan belajar-mengajar menjadi lebih menyenangkan dan dapat mempersingkat waktu mengajar. Penelitian menunjukkan bahwa individu tuna rungu lebih terfokus pada materi pelajarannya dibandingkan dengan cara konvensional. Metode ini membuat orang belajar $40 \%$ lebih cepat dibandingkan dengan metode konvensional.

Arsyad (2014) Power Point merupakan suatu softwere yang dirancang khusus untuk mampu menampilkan program multimedia dengan menarik, mudah dalam pembuatan, mudah dalam penggunaan dan relative murah, karena tidak membutuhkan bahan baku selain alat untuk menyimpan data. Sedangkan menurut Darmawan (2012) programmer pembelajaran berbasis komputer sangatlah menguntungkan hal ini dapat dilihat dari beberapa versi yaitu Power Point fasilitasnya dapat digunakan untuk memprogram model pembelajaran interaktif.

\section{SIMPULAN}

Berdasarkan pembahasan hasil penilitian, maka dapat disimpulkan bahwa penggunaan media kartu kotif berbasis animasi power point efektif dalam meningkatkan kemampuan penjumlahan bilangan bulat siswa tunarungu kelas $\mathrm{V}$ di SLBN Pelambuan Banjarmasin.

\section{DAFTARPUSTAKA}

Suningsih, A \& Arnidha, Y. 2017. Komunikasi Matematis Siswa Tunarungu Melalui Model Pembelajaran Think Pair Share. Aksioma Jurnal Pendidikan Matematika FKIP Univ. Muhammadiyah Metro. Vol. 6, No. 3.

Salim, A. 2016. Pembelajaran Matematika Berbasis Komputer Dengan Metode Multikomunikasi Untuk Siswa Kelas IV SDLB-B. Jurnal Informatika, Vol. III No. 1.

Hidayat, R dan Suherman. 2016. Kemampuan Komunikasi

Matematis Siswa Tunarungu Pada Pembelajaran Matematika Di SMPLB-B PKK Provinsi Lampung. Jurnal Pendidikan Progresif, Vol. VI No. 1. 
Sadja'ah, E. 2005. Bina Bicara Persepsi

Bunyi dan Irama. Proyek

Pendidikan Tenaga Guru

Jakarta: Dikti Depdikbud.

Darmawan, D. 2012. "Pendidikan

Teknologi Informasi dan

Komunikasi". Bandung. PT

Remaja Rosdakarya.

Arsyad, A. 2014. Media Pembelajaran.

Jakarta: PT Rajagrafindo

Persada

Undang-Undang No. 20 tahun 2003

tentang Sistem Pendidikan

Nasional

Asnawir \& M. Basyiruddin Usman. 2001. Media Pembelajaran,. Jakarta: Ciputat Pers.

Swanwick, R., Oddy, A., \& Roper, T. (2005). Mathematics and Deaf Children: An Exploration of Barriers to Success. Deafness $\mathcal{E}$ Education International, 7(1), 121.doi:10.1179/14643150579056 0446

Tanridiler, A., Uzuner, Y., \& Girgin, U. (2015). Teaching and Learning Mathematics with Hearing Impaired Students. The Anthropologist, 22(2), 237248.doi:10.1080/09720073.2015. 11891874.

Kelly R.R, Lang H.G, Pagliaro C.M. 2003. Mathematics word problem solving for deaf education: A survey of practices in grades: 6-12.
Journal of Deaf Studies and Deaf Education, 8: 104-119.

Nurhizra. 2018. Peningkatan Hasil Belajar Siswa Tentang Operasi Hitung Penjumlahan Dan Pengurangan Bilangan Bulat Dengan Menggunakan Alat Peraga Kartu Positif Dan Negatif Di Kelas V SDN Tondo G. Jurnal Kreatif Online, Vol. 6 No. 2 ISSN 2354-614X.

Alfirdausi, AH. 2011. Pengaruh Kartu KOTIF (Koin Psitif Negatif) Terhadap Hasil Belajar Matematika Siswa. Skripsi Jakarta. Jurusan Pendidikan Matematika FITK UIN Syarif Hidayatullah Jakarta.

Kustiati, D. 2014. Meningkatkan Hasil Belajar Siswa Kelas IV SDN 2 Patukuki Pada Pokok Bahasan Penjumlahan dan Pengurangan Bilangan Bulat Melalui Pembelajaran Menggunakan Media Kartu. Jurnal Kreatif Online, Vol. 2 No. 2 ISSN 2354-614X. 